\title{
A rapid and efficient method to evaluate the infection of major DNA viruses in sweet potato seedlings and tubers
}

Qili LIU ( $\square$ liuqili2002@cau.edu.cn )

Henan Institute of Science and Technology https://orcid.org/0000-0002-6981-7874

Feng Zhou

Henan Institute of Science and Technology

Puwen Song

Henan Institute of Science and Technology

Yongqiang $\mathrm{Li}$

Beijing University of Agriculture

\section{Methodology}

Keywords: sweet potato, DNA viruses, co-infection, sweepoviruses, SPBV-B, and SPSMV-1

Posted Date: August 23rd, 2021

DOI: https://doi.org/10.21203/rs.3.rs-817804/v1

License: (9) (1) This work is licensed under a Creative Commons Attribution 4.0 International License. Read Full License 


\section{Abstract \\ Background}

Sweet potato is an important food crop in China which is the fifth largest staple crop next to rice, wheat, maize, and soybean. Recent years the destroy infecting by DNA viruses in sweet potato was more and more serious. Three DNA viruses (sweepoviruses, Badnavirus and Mastrevirus) are major agents in viral diseases of sweet potato in China. It is necessary to establish a rapid and efficient method to evaluate the health of sweet potato seedlings and tubers,which will greatly affect the yield, quality of tubers and seeding circulation of sweet potatoes. Sweepoviruses were a group phylogenetically distinct from other begomoviruses that infects plants of the family Convolvulaceae including sweet potato. Sweet potato symptomless virus 1 (SPSMV-1) is the only species of Mastrevirus which can infected sweet potato. Sweet potato Badnavirus B (SPBV-B) are non-enveloped bacilliform DNA viruses with a monopartite genome which belonged to the genus Badnavirus of the family Caulimoviridae and was first found in sweet potato in 2009. As the mixed infection of these viruses is very common, rapid detection is required for etiologic diagnosis.

\section{Results}

In this study, a rapid and efficient method to evaluate the infection of major DNA viruses (sweepoviruses, Badnavirus and Mastrevirus) in sweet potato seedlings and tubers was developed and applied. A mixture of three pairs of primers was used for amplification of viral nucleic acids, yielding three different amplicons with sizes of 750 bp, 147 bp and 396 bp for sweepoviruses, Badnavirus and Mastrevirus respectively. The specificity and sensitivity of multiplex PCR were also evaluated. A total of 65 sweet potato samples with virus-like symptoms cuttings and storage roots from Henan province in China were collected between June 2019 and July 2021. They were tested for the presence of three DNA viruses by multiplex PCR which showed sweepoviruses, Badnavirus and Mastrevirus infections were $60.0 \%, 36.7 \%$, and $43.3 \%$ respectively. Co-infections with three viruses, sweepoviruses and Badnavirus, sweepoviruses and Mastrevirus, Badnavirus and Mastrevirus were identified in different samples (the detection ratio of co-infections was $13.3 \%, 20.0 \%, 13.3 \%$, and $10.0 \%$ respectively).

\section{Conclusions}

In the current situation of frequent virus mixed infection in sweet potatoes, this method is the first report on a simple assay and may be a potentially useful for apid and efficient method to evaluate the infection of major DNA viruses in sweet potato seedlings and tubers in China.

\section{Background}

Sweet potato, Ipomoea batatas (L.) Lam. (family Convolvulaceae), is an important food crop, is ranked third among all crops worldwide, and its calorific contribution to the human diet is ranked fifth globally [1]. Most sweet potatoes are planted in some countries of eastern Asia, and $80 \%$ of which are produced in China [2], the largest producer of sweet potatoes in the world [3]. In China, sweet potato is the fifth largest staple crop next to rice, wheat, maize, and soybean [4]. The planting area for sweet potato in China had reached $2.38 \times 10^{6}$ ha. and yield of $5.32 \times$ $10^{7}$ tons in 2018 [5]. Sweet potato was extensively cultivated in sixteen provinces or municipalities of China with 
over $1.0 \times 10^{4} \mathrm{hm}^{2}$ which include Henan province [6, 7]. Henan province was a major production area in North China which had about $4 \times 10^{5}$ hectares every year.

Recent years the destroy infecting by DNA viruses in sweet potato was more and more serious. Geminiviruses cause destructive diseases in many crops worldwide recent years and seriously threaten crop production.

Begomovirus and Mastrevirus of family Geminiviridae all can infect sweet potato plants [1]. The begomoviruses further showed a clear subdivision into four groups: New World, Old World, legumoviruses and sweepoviruses [8, 9]. Sweepoviruses were a group phylogenetically distinct from other begomoviruses that infects plants of the family Convolvulaceae including sweet potato [8]. Only one species of Mastrevirus (sweetpotato symptomless virus 1, SPSMV-1) had been reported in Peru, Tanzania, several central American countries and China [1, 10-13]. Sweet potato Badnavirus B (SPBV-B) are non-enveloped bacilliform DNA viruses with a monopartite genome containing about 7.2 to $9.2 \mathrm{~kb}$ of dsDNA which belonged to the genus Badnavirus of the family Caulimoviridae. SPBV-B was first found in sweet potato (Ipomoea batatas) plants in 2009[10].

Detection for DNA viruses was different from that for RNA viruses. As SPBV-B, SPSMV-1 and sweepoviruses compound infections were often with no specific symptoms observed, and the antibody detection had not been making and used as the diagnostic assay for the compound infections, polymerase chain reaction (PCR) became a better detection method which had the advantages of high sensitivity and high specificity. Current routine PCR assays require three separate primer sets and three separate reactions to differentiate the three viruses. In contrast, multiplex PCR made it possible to amplify multiple target sequences in a single reaction tube by using multiple primer pairs. The advantage of a multiplex PCR for the simultaneous detection and differentiation among SPBV-B, SPSMV-1 and sweepoviruses was that it combines the sensitivity and rapidity of PCR and avoids the need to test sweet potato samples separately for each virus. This paper first described the development of a multiplex PCR assay for the simultaneous detection and differentiation of SPBV-B, SPSMV-1 and sweepoviruses in sweet potato seedings and tubers collected from farms, seedbeds and germplasm repository.

\section{Results}

\section{Cloning of PCR amplified Sweepoviruses, SPSMV-1, and SPBV-B genes}

Viral DNA extracted from the sweet potato samples was used as the template for PCR. The amplified PCR products were then analyzed by $1 \%$ agarose gel electrophoresis. The sweepoviruses coat protein regions, SPBV-B partial movement and coat protein genes, and movement protein regions of SPSMV-1 were $750 \mathrm{bp}, 147 \mathrm{bp}$, and $396 \mathrm{bp}$ respectively (Fig. 1A-a). These three target fragments were cloned into the PGEM-T Easy Vector, and the resulting plasmids were used as standardized positive-control plasmids containing cloned viral gene. The positive plants infected by different virus were determined.

\section{The multiplex PCR was suitable for detection three viruses}

To determine whether the multiplex PCR were suitable for detection of the three viruses, the positive plasmids were used as templates in multiplex PCR under the same conditions used for sweet potato plants samples. When multiplex PCR to detect the positive controls containing one virus was performed, the reactions yielded the expected size (Fig. 1A-a, Line 1-3). For the detection of two and three viruses in plasmids and DNA of sweet 
potato plants samples, multiplex PCR amplications were carried out with size-distinguishable standardized positive-controls. Positive samples of two viruses (SPSMV-1 and SPBV-B) were detected as shown by the $396 \mathrm{bp}$ and the $147 \mathrm{bp}$ (Fig. 1A-b). The $750 \mathrm{bp}$ and the $147 \mathrm{bp}$ amplified band were detected in positive plasmids and sweet potato plants containing sweepovirus and SPBV-B (Fig. 1A-C). The positive samples harboring three viruses were detected as shown by the 750 bp, $396 \mathrm{bp}$ and $147 \mathrm{bp}$ amplified band (Fig. 1A-d). Negative control was not detected. The minimum number of copies of SPLCV, SPBV-B and SPSMV- 1 were $1.02 \times 10^{6}$ copies/uL, $1.57 \times 10^{4}$ copies/uL and $2.54 \times 10^{3}$ copies/uL, which was a sensitive detection method.

\section{Detection of three viruses in sweet potato samples collected from the farms}

Total thirty positive samples were detected from 65 sweet potato samples, which including 22 sweet potato cuttings and 8 sweet potato storage roots (Table 2). These sweet potato samples varied in variety (Table 2). Among the thirty positive samples, eighteen sweet potato samples were found to be SPLCV (a species of sweepoviruses) positive (18/30,60.0\%) (Table 2, Fig. 2). Eleven sweetpotato samples were found to be SPBV-B positive (11/30, 36.7\%) (Table 2). Thirteen SPSMV-1-positive samples were found from three farms of the north area of Henan province $(13 / 30,43.3 \%)$ (Table 2$)$. SPBV-B was not detected in any sweet potato storage roots. All samples with leaf curl symptoms were SPLCV positive (Table 2, Fig. 2A). Many samples showed the compound infection of two $(12 / 30,40.0 \%)$ or three viruses $(4 / 30,13.3 \%)$. The symptoms of sweet potato infected by the mixed viruses were diverse and irregular (Table 2, Fig. 2B). 
Table 1

Collection information and detection results of 30 positive samples from 65 samples for testing in this study

\begin{tabular}{|c|c|c|c|c|}
\hline Collecting sites(City) & $\begin{array}{l}\text { Variety of sweet } \\
\text { potato }\end{array}$ & $\begin{array}{l}\text { Sample } \\
\text { types }\end{array}$ & Virus & Symptoms \\
\hline \multirow[t]{6}{*}{ Huixian } & Zhenghong22 & Cuttings & $\begin{array}{l}\text { SPLCV; SPBV; } \\
\text { SPSMV-1 }\end{array}$ & $\begin{array}{l}\text { Leaf curl; leaf } \\
\text { shriveling }\end{array}$ \\
\hline & & Storage roots & SPLCV; SPSMV-1 & Asymptomatic \\
\hline & Hongxiangjiao & Cuttings & $\begin{array}{l}\text { SPLCV; SPBV; } \\
\text { SPSMV-1 }\end{array}$ & Leaf curl; vein enation \\
\hline & & Storage roots & SPSMV-1 & Asymptomatic \\
\hline & Shangshu19 & Cuttings & SPLCV; SPBV; & Leaf curl; \\
\hline & & Storage roots & SPSMV-1 & Asymptomatic \\
\hline \multirow[t]{2}{*}{ Fengqiu } & Shangshu19 & Cuttings & SPBV; SPSMV-1 & $\begin{array}{l}\text { Fan-shaped leaves; } \\
\text { vein enation }\end{array}$ \\
\hline & Xinxiang & Cuttings & SPLCV; SPBV & Leaf curl \\
\hline \multirow[t]{3}{*}{ Nanyang } & Longshu9 & Cuttings & SPSMV-1 & Fan-shaped leaves \\
\hline & Yushu12 & Cuttings & SPSMV-1; SPBV; & Mosaic \\
\hline & Sushu & Cuttings & SPLCV; SPBV & Leaf curl; \\
\hline \multirow[t]{3}{*}{ Anyang } & Longshu9 & Cuttings & SPBV; & Leaf curl; vein enation \\
\hline & Jishu4 & Cuttings & SPBV; SPSMV-1 & Stunting; vein yellowing \\
\hline & Shangshu19 & Cuttings & SPLCV; SPBV & Leaf curl \\
\hline \multirow[t]{5}{*}{ Kaifeng } & Ziluolan & Cuttings & SPSMV-1 & Chlorosis; stunting \\
\hline & Yushu12 & Cuttings & SPLCV; SPSMV-1 & Leaf malformation \\
\hline & Shangshu19 & Cuttings & SPLCV; SPBV; & $\begin{array}{l}\text { Leaf curl; vein } \\
\text { yellowing }\end{array}$ \\
\hline & Longshu9 & Cuttings & SPSMV-1 & $\begin{array}{l}\text { Leaf curl; Fan-shaped } \\
\text { leaves }\end{array}$ \\
\hline & Jishu26 & Cuttings & SPLCV & Leaf curl \\
\hline \multirow[t]{3}{*}{ Shangqiu } & Shangshu19 & Cuttings & SPLCV; SPSMV-1 & Leaf curl \\
\hline & Yushu12 & Cuttings & SPLCV & Leaf curl; \\
\hline & Xinxiang & Cuttings & $\begin{array}{l}\text { SPLCV; SPSMV-1; } \\
\text { SPBV }\end{array}$ & Stunting; Chlorosis \\
\hline \multirow[t]{2}{*}{ Luoyang } & Yushu8 & Cuttings & SPLCV; SPBV & Leaf curl; \\
\hline & & Storage roots & SPLCV & Asymptomatic \\
\hline
\end{tabular}

Full name of virus species and abbreviations: sweet potato leaf curl virus (SPLCV, a common species of sweepovirus); sweet potato Badnavirus B(SPBV-B); sweet potato symptomless virus 1(SPSMV-1) 


\begin{tabular}{|lllll|}
\hline Collecting sites(City) & $\begin{array}{l}\text { Variety of sweet } \\
\text { potato }\end{array}$ & $\begin{array}{l}\text { Sample } \\
\text { types }\end{array}$ & Virus & Symptoms \\
\hline Longshu9 & Cuttings & SPSMV-1 & Chlorosis; stunting \\
\hline & Xinxiang & Storage roots & SPSMV-1 & Asymptomatic \\
\hline Xuttings & $\begin{array}{l}\text { SPLCV; SPSMV-1; } \\
\text { SPBV }\end{array}$ & $\begin{array}{l}\text { Leaf curl; vein } \\
\text { yellowing }\end{array}$ \\
\hline & Storage roots & SPLCV & Asymptomatic \\
\hline $\begin{array}{l}\text { Full name of virus species and abbreviations: Sweet potato leaf curl virus (SPLCV, a common species of } \\
\text { sweepovirus); sweet potato Badnavirus B(SPBV-B); sweet potato symptomless virus 1(SPSMV-1) }\end{array}$ & Storage roots & SPLCV & malformation \\
\hline
\end{tabular}

Table 2

Primers used to detect three genus of DNA viruses infecting sweet potato in China

\begin{tabular}{|c|c|c|c|c|}
\hline $\begin{array}{l}\text { Primer } \\
\text { name }\end{array}$ & Primer sequence $(5 \rrbracket-3 \rrbracket)$ & $\begin{array}{l}\text { Size of } \\
\text { PCR } \\
\text { products } \\
\text { (bp) }\end{array}$ & Primer universality & $\begin{array}{l}\text { Virus } \\
\text { (Genus) }\end{array}$ \\
\hline $\begin{array}{l}\text { MA292 } \\
\text { MA293 }\end{array}$ & $\begin{array}{l}\text { CCY TAG GGT TCG AGC TVT } \\
\text { GTT CGG TTT ATT AAT TDT } \\
\text { TRT GCG AAT C }\end{array}$ & 750 & Sweepovirus (CP gene region) & Begomovirus \\
\hline $\begin{array}{l}\text { rt-badB- } \\
\text { F rt- } \\
\text { badB-R }\end{array}$ & $\begin{array}{l}\text { TCGGCAGTAACAGACTACTTGG } \\
\text { TCTGCTTATCATCTCCGTTGG }\end{array}$ & 147 & Sweet potato Badnavirus $B$ & Badnavirus; \\
\hline $\begin{array}{l}\text { MastvKF } \\
\text { MastvsR }\end{array}$ & $\begin{array}{l}\text { GACAGACCCCTAGGGTGA } \\
\text { ACTGCATATAGTACATGCCACA }\end{array}$ & 396 & Sweet potato symptomless virus 1 & Mastrevirus \\
\hline $\mathrm{Y}=\mathrm{C}, \mathrm{T} ; \mathrm{V}$ & $A, C, G ; D=A, G, T ; R=A$ or $G$ & & & \\
\hline
\end{tabular}

\section{Discussion}

DNA viruses infecting sweet potato were detected successively in recent years which caused more attentions in China. In this study, sweepoviruses had the most detection frequency in the sweet potato plants collected from farms of Henan province which were all identified as SPLCV species. Thus, it can be seen that SPLCV was a dominant species of sweepoviruses in sweet potato planting area of Henan province which was similar to the situation all over the country in China[14]. The frequency of SPSMV-1 and SPBV-B were all more than $35 \%$ among the positive samples and often mixed infected with SPLCV in a same sweet potato plant.

As the mixed infection of the DNA viruses was found frequently in sweet potato seedlings, plants and storage roots, strict quarantine based on fast and reliable detection method in sweet potato transport was very important. Multiplex PCR is an efficient detection method which has been reported widely in many research fields [15-17]. This method had been used appropriately for the simultaneous detection of the above three viruses although it was not considered novel. Multiplex PCR was an efficient and convenient detection method which only need to extract DNA of sweet potato samples and amplified in a proper reaction system. The selection of primers and their 
proportion used in the multiplex PCR system were the key in detecting virus genes. Different proportion of primers were compared and the optimum ratio 4:3:3 of three pairs of primers (MA292 and MA293, rt-badB-F and rt-badB-R, MastvKF and MastvKR) was identified finally. The expected bands $750 \mathrm{bp}, 396 \mathrm{bp}$ and $147 \mathrm{bp}$ were specific and size-distinguishable in this identified multiplex PCR system.

Among the symptoms of positive sweet potato samples infected by SPLCV, SPSMV-1, SPBV-B, and mixed infection of two or three viruses, leaf curl was the most common symptom (Table 2). Liu et al. reported that leaf curl symptom may be an important diagnosis basis for sweet potato infected by sweepoviruses [14]. We can infer those symptoms caused by SPLCV maybe masked those of the other two viruses. The symptoms can not reflect the necessary connection among different virus infections. Most storage roots infected by DNA viruses showed asymptomatic which remind us the importance of testing viruses in the trade and transport of sweet potato storage roots.

\section{Conclusion}

This method may be a potentially useful for rapid, sensitive, and cost-effective etiological diagnostic tool for compound infection of three frequent DNA viruses infecting sweet potato.

\section{Methods}

\section{Viral DNA preparation and single PCR reaction}

Sweet potato cuttings with serious virus disease were obtained from different farms and seedbed. The varieties of sweet potato were Shangshu19, Xushu22 and Xinxiang respectively. DNA was extracted from these sweet potato cuttings using the universal genomic DNA extraction kit (TaKaRa, China) following the protocol of the manufacturer. These DNA extractions were frozen at $-80^{\circ} \mathrm{C}$ until analysis.

Single PCR reactions were conducted using three specific primer sets for PCR assay to amplify the three DNA viruses respectively: sweepovirus, SPBV-B and SPSMV-1 (Table 2). The primers MA292 and MA293, located in the $\mathrm{CP}$ region, were used to detect highly specific for sweepovirus [8]. The primers rt-badB-F and rt-badB-R (Table 2), corresponding to movement and coat protein genes, were used for detecting SPBV-B [12]. The primers MastvKF and MastvsR (Table 2), located in the V1 gene region, were used to amplify movement protein of SPSMV-1[11]. All of the amplified PCR products were ligated to pMD19-T vector (TaKaRa, China). The ligated product was transformed into Escherichia coli (DH5a) competent cells, and the positive clones were sent to Sangon Biotech (Shanghai, China) for sequencing.

\section{Multiplex PCR reaction detecting three viruses}

Each multiplex PCR mixture contained 100ng/uL DNA template which was extracted from the prepared sweet potato plants infected by one, two, and three viruses, $0.4 \mathrm{mmol} / \mathrm{L}$ each of sweepovirus primers (MA292 and MA293), $0.3 \mathrm{mmol} / \mathrm{L}$ each of SPBV-B primers (rt-badB-F and rt-badB-R), 0.3mmol/L each of SPSMV-1 primers (Mastv KF and Mastv KR), $0.2 \mathrm{mmol} / \mathrm{L}$ each of dNTP, 10×PCR buffer (Takara, China), $1.0 \mathrm{mmol} / \mathrm{L} \mathrm{MgCl}_{2}$ and $5 \mathrm{U}$ of Taq DNA Polymerase (Takara, China). The following thermocycling profile was used for three virus multiplex PCR: $94^{\circ} \mathrm{C}$ for $3 \mathrm{~m}$ ( 1 cycle); $94^{\circ} \mathrm{C}$ for $45 \mathrm{~s}, 51^{\circ} \mathrm{C}$ for $50 \mathrm{~s}, 72^{\circ} \mathrm{C}$ for $50 \mathrm{~s}$ ( $35 \mathrm{cycles}$ ), and then $72^{\circ} \mathrm{C}$ thereafter. PCR products were separated in $1 \%$ agarose gels, stained with ethidium bromide and visualized by ultraviolet light. 
To assess the specificity of the multiplex PCR assay, recombinant plasmids of three virus partial genome sequence were used as templates to amplified respectively under the conditions described above. Various amounts of recombinant plasmid DNAs (105 101 copies) of the virus were used as templates to determine the sensitivity of the PCR assay. To evaluate the efficiency of detecting co-infection with three viruses, serial dilutions (105 101 copies) of every virus were co-amplified with a fixed copy number (104 copies) of the other viral DNA samples. To determine the sensitivity of the multiplex PCR assay, various amounts of three recombinant plasmids were prepared.

\section{Application to sweet potato samples collected from farms, seedbeds and germplasm repository}

To determine the extent of the above sweet potato viral infections in Henan province, a total of 65 sweet potato samples including forty seedings with virus-like symptoms and twenty-five storage roots were obtained randomly from the farms of twenty different cities in Henan province of China. The multiplex PCR assay was used to simultaneously detect the three viruses. The expected PCR products (750-, 147-bp and 396 fragments) were confirmed by sequencing.

\section{Abbreviations}

SPSMV-1

sweetpotato symptomless virus 1

SPBV-B

sweet potato Badnavirus B

SPLCV

sweet potato leaf curl virus

\section{Declarations}

\section{-Ethics approval and consent to participate}

The research project and this study have been approved by an ethics committee which found them conform to all national and international guidelines for conservation of endangered species. The plant materials (sweet potato seedings and tubers collecting from different regions) used are common varieties which are not endangered.

\section{-Consent for publication}

Not applicable.

\section{-Availability of data and material}

All data generated or analyzed during this study are included in this published article and its supplementary information files. The datasets used and/or analyzed during the current study are available from the corresponding author on reasonable request.

\section{-Competing interests}

The authors declare that they have no competing interests. 


\section{-Funding}

This research was funded by the National Natural Science Foundation of China (31801707), Postdoctoral Research Grant in Henan Province (001701038); the views expressed in this work are the sole responsibility of the authors and do not necessary reflect the views of the funding body. The funding body did not play any role in the design of the study nor in the collection, analysis and interpretation of data, nor in the writing of the manuscript.

\section{-Authors' contributions}

QL designed and performed the research and wrote the paper; F and PW performed the research; $Y Q$ revised the manuscript critically. All authors read and approved the final manuscript.

\section{-Acknowledgements}

The authors gratefully acknowledge research assistants Junli Li and Lingyan Wang (Henan Xinxiang Academy of Agricultural Sciences, China) for providing some samples for testing.

\section{References}

1. de Albuquerque TMR, Sampaio KB, de Souza EL. Sweet potato roots: unrevealing an old food as a source of health promoting bioactive compounds-a review. Trends Food Sci Technol. 2019;85:277-86.

2. Anonymous: International Potato Center: World Sweetpotato Atlas. 2007.

3. Tairo F, Mukasa SB, Jones RAC, Kullaya A, Valkonen JPT. Unravelling the genetic diversity of the three main viruses involved in Sweet Potato Virus Disease (SPVD), and its practical implications. Mol Plant Pathol. 2005;6:199-211. http://doi. 10.1111/J.1364-3703.2005.00267.X.

4. Zhang LM, Wang QM, Liu QC, Wang QC: Sweetpotato in China. In: Biology and Biotechnology of Sweetpotato.: Eds: Loebenstain G. and Thottappilly G, Springer Netherland; 2009.

5. FAOSTAT. 2018. Available from: http://faostat.fao.org/.

6. Lu SY, Liu QC, Li WJ. Sweet potato Breeding. Beijing: Chinese Agricultural Press; 1998.

7. Ma DF, Li Q, Cao QH, Niu FX, Xie YP, Tang J, Li HM. Development and prospect of sweetpotato industry and its technologies in China (in Chinese). Jiangsu J Agr Sci. 2012;28:969-73.

8. Lozano G, Trenado HP, Valverde RA, Navas-Castillo J. Novel begomovirus species of recombinant nature in sweet potato (Ipomoea batatas) and Ipomoea indica: taxonomic and phylogenetic implications. J Gen Virol. 2009;90:2550-62.

9. Zerbini FM, Briddon RW, Idris A, Martin DP, Moriones E, Navas-Castillo J, Rivera-Bustamante R, Roumagnac P, Varsani A, Consortium IR. ICTV Virus Taxonomy Profiles: Geminiviridae. J Gen Virol. 2017;98:131-3.

10. Kreuze JF, Perez A, Untiveros M, Quispe D, Fuentes S, Barker I, Simon R. Complete viral genome sequence and discovery of novel viruses by deep sequencing of small RNAs: A generic method for diagnosis, discovery and sequencing of viruses. Virology. 2009;388:1-7.

11. Mbanzibwa DR, Tairo F, Gwandu C, Kullaya A, Valkonen JPT. First Report of Sweetpotato symptomless virus 1 and Sweetpotato virus A in Sweetpotatoes in Tanzania. Plant Dis. 2011;95:224.

12. Kashif M, Pietilä S, Artola K. Detection of viruses in sweetpotatoes from Honduras and Guatemala augmented by Deep-Sequencing of small-RNAs. Plant Dis. 2012;96:1430-7. 
13. Wang YJ, Zhang DS, Zhang ZC, Wang S, Qiao Q, Qin YH, Tian YT. First Report on Sweetpotato Symptomless Virus 1(genus Mastrevirus family Geminiviridae) in sweetpotato in China. Plant Dis. 2015;99:1042.

14. Lefeuvre P, Hoarcau M, Delatte HEA. A multiplex PCR method discriminating between the TYLCV and TYLCYMld clades of Tomato yellow leaf curl virus. J Virol Methods. 2007;144:165-8.

15. Manzan MA, Aljinovic EM, Biedma ME, Sciocco-Cap A, Ghiringhelli PD, Romanowski V. Multiplex PCR and quality control of Epinotia aporema granulovirus production. Virus Genes. 2008;37:203-11.

16. Yue F, Cui S, Zhang C, Yoon KJ. A multiplex PCR for rapid and simultaneous detection of porcine circovirus type 2, porcine parvovirus, porcine pseudorabies virus, and porcine reproductive and respiratory syndrome virus in clinical specimens. Virus Genes. 2009;38:392-7.

17. Liu Q, Wang Y, Zhang Z, Lv H, Qiao Q, Qin Y, Zhang D, Tian Y, Wang S, Li J. Diversity of sweepoviruses infecting sweet potato in China. Plant Dis. 2017;101:2098-103.

\section{Figures}

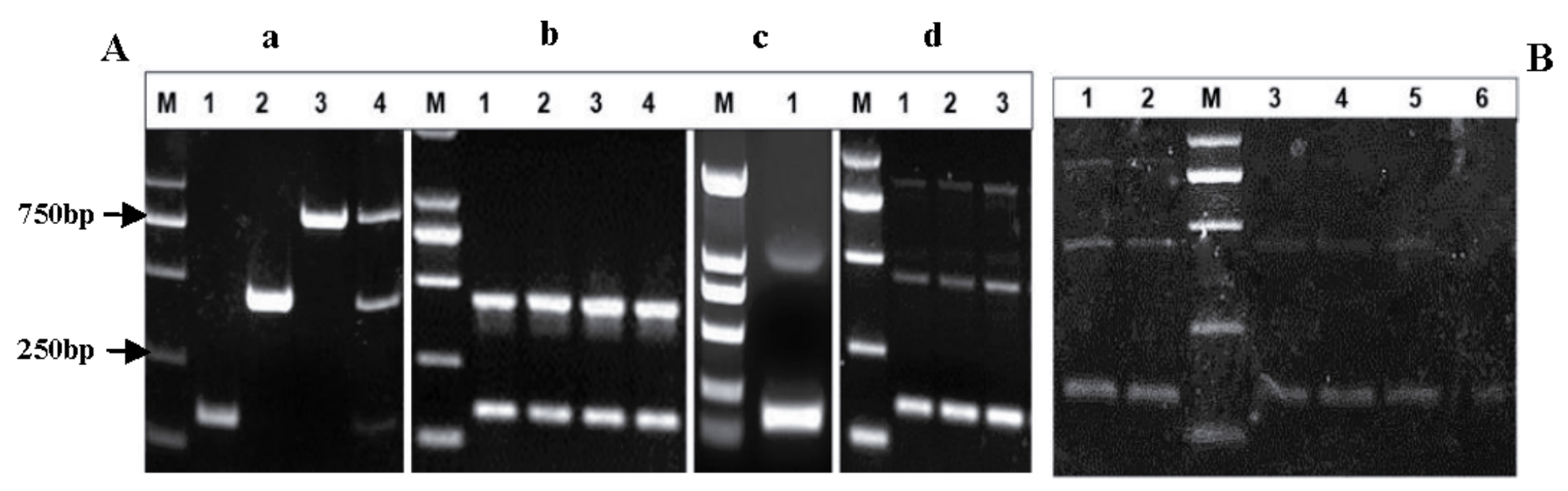

\section{Figure 1}

Specificity and sensitivity of multiplex PCR for detection of three DNA viruses infecting sweet potato M\&DL2000 DNA marker囚A: Specificity and sensitivity of multiplex PCR A-a: Lane 1: Sweet potato Badnavirus B; Lane 2: Sweet potato symptomless virus 1; Lane 3: Sweepoviruses infecting sweet potato; Lane 4囚Mixed plasmids of three DNA viruses; A-b: Lane 1-4: Mixed plasmids of Sweet potato Badnavirus B and Sweet potato symptomless virus 1; A-c: Lane 1: Mixed plasmids of sweepoviruses and Sweet potato Badnavirus B; A-d: Lane 1-3: Mixed plasmids of three

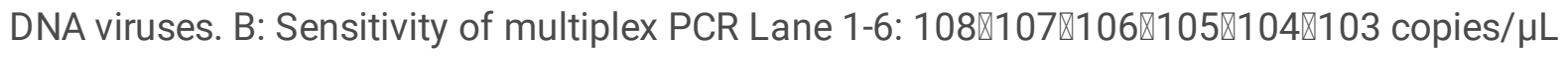


A
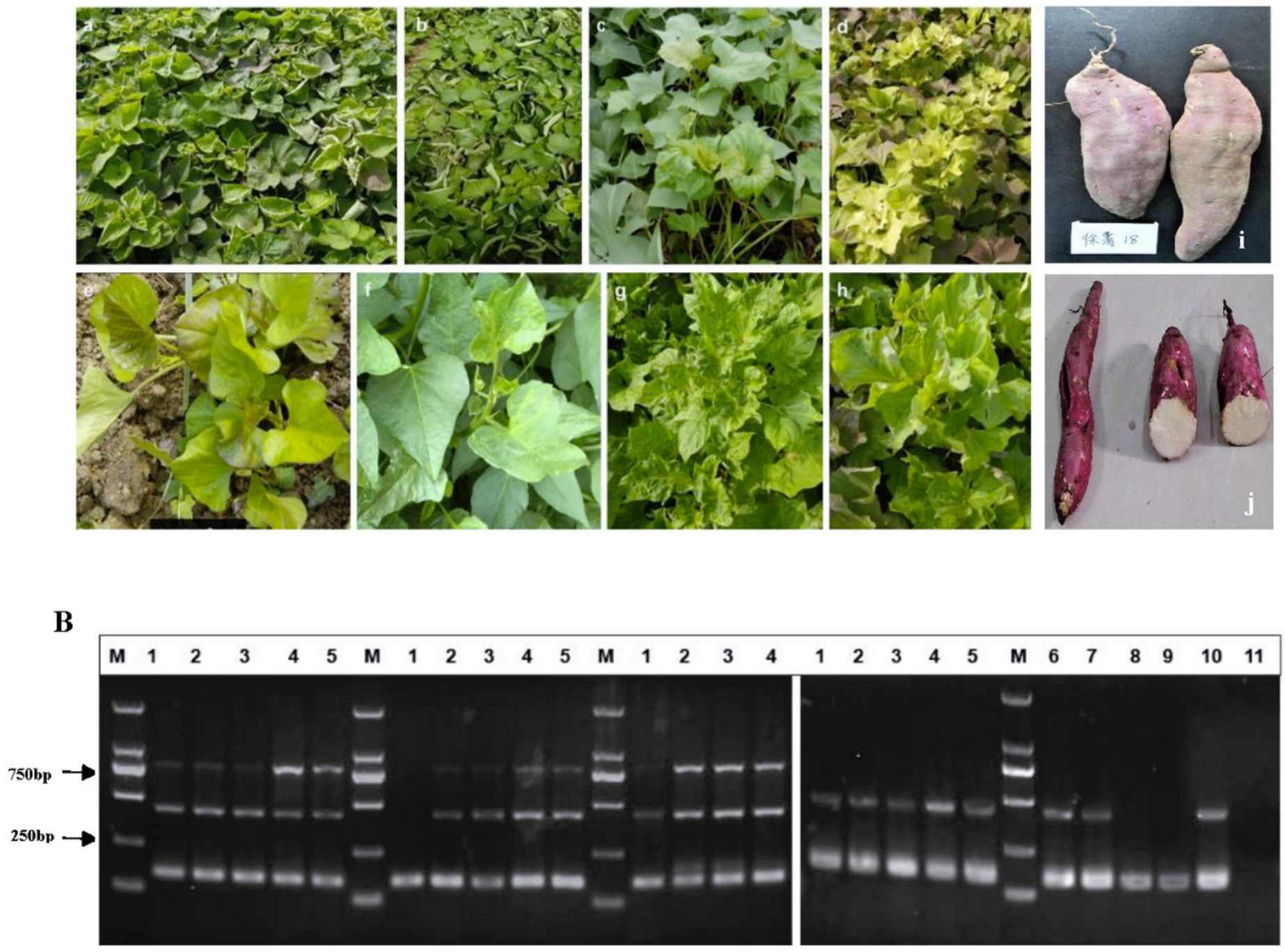

\section{Figure 2}

Symptoms on sweet potato samples and multiplex PCR results for detection of three DNA viruses A: Symptoms on sweet potato samples a and b: leaf curl; c: vein enation; $d$ : leaf malformation and chlorosis; e: fan-shaped leaves; $f$ : chlorotic spots mosaic and leaf malformation; g: stunting and vein yellowing; h: fan-shaped leaves; i: surface uneven; j: asymptomatic B: Multiplex PCR for detection of three DNA viruses from different samples a-d: Viruses detected in the multiplex PCR using different sweet potato DNA samples (repeat 2-3 times per sample). 